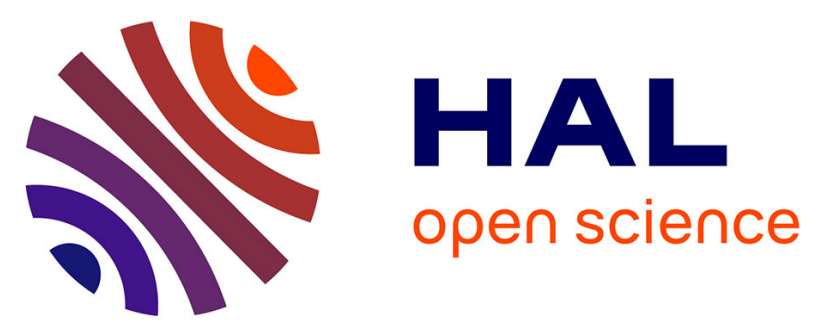

\title{
Reply to the comment by A. Revil on "Review of Self-potential methods in Hydrogeophysics" by L. Jouniaux et al. [C. R. Geoscience 341 (2009) 928-936]
}

Laurence Jouniaux, Alexis Maineult, Véronique Naudet, Marc Pessel, Pascal Sailhac

\section{To cite this version:}

Laurence Jouniaux, Alexis Maineult, Véronique Naudet, Marc Pessel, Pascal Sailhac. Reply to the comment by A. Revil on "Review of Self-potential methods in Hydrogeophysics" by L. Jouniaux et al. [C. R. Geoscience 341 (2009) 928-936]. Comptes Rendus Géoscience, 2010, 342 (10), pp.810-813. 10.1016/j.crte.2010.07.002 . hal-00641691

\section{HAL Id: hal-00641691 https://hal.science/hal-00641691}

Submitted on 16 Nov 2011

HAL is a multi-disciplinary open access archive for the deposit and dissemination of scientific research documents, whether they are published or not. The documents may come from teaching and research institutions in France or abroad, or from public or private research centers.
L'archive ouverte pluridisciplinaire HAL, est destinée au dépôt et à la diffusion de documents scientifiques de niveau recherche, publiés ou non, émanant des établissements d'enseignement et de recherche français ou étrangers, des laboratoires publics ou privés. 
Please cite this article as: L. Jouniaux, A. Maineult, V. Naudet, M. Pessel, and P. Sailhac, Reply to the comment by A. Revil on "Review of Self-potentialmethods in Hydrogeophysics"' by L. Jouniaux et al.[C. R. Geoscience 341 (2009) 928-936], C.R. Geoscience 342, 810-813, 2010

\section{Reply to the comment by A. Revil on "Review of Self-potential methods in} Hydrogeophysics”, by L Jouniaux et al. [C.R. Geoscience 341 (2009) 928-936]

\section{Laurence Jouniaux 1 , Alexis Maineult2, Véronique Naudet 3 , Marc Pessel4, and Pascal Sailhac1}

1. Institut de Physique du Globe de Strasbourg, UMR7516, CNRS et Université de Strasbourg (EOST), France

2. CNRS and PRES Sorbonne Paris Cité - Institut de Physique du Globe de Paris UMR7154, Paris, France

3. Université Bordeaux 1, Laboratoire GHYMAC-EA 4134 (Géosciences Hydrosciences Materiaux Constructions), Talence, and BRGM (French Geological Survey), Orléans, France

4. Laboratoire I.D.E.S., UMR 8148 CNRS/Université de Paris-Sud XI, 91405 Orsay, France.

Corresponding author: L. Jouniaux, CNRS/IPGS, 5 rue René Descartes, 67000 Strasbourg, France. Ph : 333688503 34/ fax : 33368850125. l.jouniaux@unistra.fr

We did not discuss subjects that are still not well understood and still being debated since the title of our paper includes "review". We did not review and discuss all aspects of the theoretical background based on microscaled thermodynamics because we focused on field applications in hydrogeophysics. Moreover we submitted our manuscript in 2008 and thus did not acknowledge any paper published in 2009. However this comment is of interest because it gives us the opportunity to provide more precision by answering some points.

We agree that there is an increasing number of publications in this field. Recently, electrokinetic models have been proposed for reservoir geophysics and petroleum investigation [28, 49]. New applications have also been developed, such as the use of SP measurements in boreholes as an electrical flowmeter [44]. Initially, we did not include it, but the electrokinetic coupling is also directly involved in seismoelectromagnetics effects $[9,10,16,20,24$, $27,52]$. For hydrological applications, it is difficult to infer a steady link between SP intensity and water flux $[11,15,30]$ or deformation [25, 29], although some authors have proposed to predict the permeability by using electrokinetic theory [22, 23]. 
We obviously agree that our eq. (1), which expresses the phenomenological law between fluxes and forces, is valid only close to thermodynamic equilibrium. This has been known for a long time and was already mentioned by Onsager and Nourbehecht [40,41]. Indeed, these constitutive laws are used by many authors to interpret and to model self-potential observations $[18,19,26,35,36,42,51,55]$. Far from equilibrium, high-order terms must be considered, but the linear case is sufficient for the interpretation of most of the field situations encountered by hydrogeophysicists. Finally, to our knowledge, A. Revil did not develop any theory describing the constitutive laws valid far from the thermodynamic equilibrium. Indeed, even when $A$. Revil considers chemical potentials and combines several thermodynamic forces, he uses fluxes related through linear relationships in a symmetric Onsager coupling matrix; this basically follows classical theory of irreversible thermodynamics near equilibrium $[13,14,53]$.

The fact that the flow state can affect the streaming potential was shown experimentally before the work cited by A. Revil (his reference 4). For instance, an experimental study performed by Watanabe and Katagishi [54] on granular materials showed that the fluid flow began to deviate from Darcy's law at a Reynolds number larger than 3, and that streaming potentials began to deviate from the linear relation at larger Reynolds numbers, leading to a lower than expected streaming potential. Another study from Kuwano et al. [31] showed that the streaming current coefficient (electrokinetic coefficient multiplied by the rock conductivity) was constant at low Reynolds numbers, but decreased at Reynolds numbers larger than 1-10. They showed that this decrease was much smaller than that of permeability, leading to the conclusion that non-linear laminar flow induces more streaming current per unit flow rate. Nevertheless, as stated by Fetter [17], "under most natural ground-water conditions, the velocity is sufficiently low for Darcy's law to be valid" (with Reynolds numbers of less than 1 to 10). One major exception can be the vicinity of pumping wells (e.g., reference 21 of the comment).

We proposed eq. (5) for the electrokinetic coefficient as a function of the saturation. We wrote precisely: the few observations published up to now [Guichet et al, 2003] show...eq. (5). Therefore this equation is based on the observations. The previous sentence was exactly: Based on theoretical considerations it has been proposed $[8,54]$ that the electrokinetic coefficient is inversely proportional to the effective saturation, which is not the eq. (5) we proposed, since this equation shows that the electrokinetic coefficient is proportional to the effective saturation. It is true that we refered to an experimental study, which is not verified by the model proposed by A. Revil. The model proposed by $A$. Revil uses a strong assumption, which is that the volumetric charge density in the water-saturated pore is inversely 
proportional to the water saturation. However, we do not know if this assumption is valid. The model proposed by A. Revil (in his reference 8) is able to explain some of his measurements when extrapolating the value of the electrokinetic coefficient at full saturation from values obtained at various saturations using the model that the author wants to prove. However, this model cannot explain the values at full saturation of his measurements, previously published (in his reference 9), but unfortunately not reported in his last work (his reference 8). Moreover, other models were proposed for the electrokinetic coefficient as a function of water saturation [28, 43, 49]. Recently, for the first time, an experimental study presented continuous records of the electrokinetic coefficient as a function of water saturation. It showed that the electrokinetic coefficient does not depend monotonously on the saturation [1]. Therefore, we still think that further studies are needed in this domain.

We do not challenge the general formulation proposed by A. Revil (his eq. 1) for the current densities associated with the chemical potential. But we point out that this formulation is not easy to use for modelling and interpretation, in particular because the Hittorf numbers depend on the concentration, which can evolve with space and time. The form derived from the well-known generalized ionic diffusion equations underlines more clearly the link between the electrical potential gradient (measured in the field) and its source, l.e., the relative gradient of concentration (to be deduced from the potential gradient). It has been successfully used to explain the response of a $\mathrm{NaCl}, \mathrm{FeCl}_{2}$ and $\mathrm{KCl}$ front flowing through sand [32, 33, 34].

We would also emphasize that the theoretical foundation of A. Revil's eq. (5) was first used by Arora et al. [2] from an experimental deduction by Naudet et al. [38].

Concerning the inverse problem of SP data, we do not expect great advances from the choice of the optimization method itself. Actually this choice helps, but is not the fundamental issue for breaking the non uniqueness of solutions: one should improve the accuracy of the data and the accuracy of the theory.

The recent success in connecting SP ground surface measurements to piezometric height is due essentially to the theory (use of Fournier's equation ), and only partially results from the choice of the optimization algorithm ("PSO" versus "Simplex") [39]. Indeed, other authors have previously obtained realistic results by solving equations similar to that of Fournier by deconvolution $[7,8]$ or simply by fitting sliding proportionality factors $[3,4,5$ ]. Besides, using the wavelet method is discussed because this is one step in the improvement of the theory: the relationship between the stream function of groundwater flows and SP analytic signals can be better understood when 
SP wavelet transforms are used to characterize ground water flow singularities [46]. This also allows one to reduce the non-uniqueness of the inverse problem without the need for classical regularization techniques: Tikhonov's additional terms to the data misfit function actually results in smoother models. Concerning the merit of the cross-correlation approach over wavelet-based techniques, we still invite our colleague to read Gibert and Sailhac [21]: one should not consider these methods as opposed because coefficients of "wavelet" and "cross-correlation" are essentially the same; moreover one should not use the inappropriate expression "tomography of probability" that was introduced by mistake for naming the plots of these coefficients.

Besides, we agree that improvements of SP data inversion will also come from the integration of SP data with different kinds of parameters sensitive to groundwater and more specifically to the electric conductivity tomography; this is the guideline of the work performed at the experimental site of La Soutte $[6,48]$. Nevertheless, we consider that further improvements of the theory are necessary. Although the accuracy of future SP inversion techniques might be improved by a general Bayesian framework, one needs deeper insight into the joint hydro-electric potentials; there is still a number of undefined parameters involved in the joint phenomena of actual ground water flows and electric potentials. It is true that there exist experiments of inversion methods based upon joint hydro-electric modelling tackling hydraulic parameters. Some of these joint inversion methods use analytic formulas [12, 47] or numerical modelling [37, 45, 50]. There are still limitations related to necessary improvements in modelling the behaviour of the coupling coefficients in real soils, for instance in heterogeneous or unsaturated media, multiphase or multi-fluid flows, and with various dynamics. One still needs further developments and experiments for the theory to improve hydraulic flow accuracy when inverting SP data; this is why we consider that "moving tomography of the electrokinetic source term into the tomography of some hydraulic parameters (...) is the real challenge of the next decade".

This is IPGP contribution $\mathrm{n}^{\circ} 3007$.

References

[1] V. Allègre, F. Lehmann, L. Jouniaux, P. Sailhac, P.-D. Matthey, Electrokinetics dependence on water-content in sand, NS04, A.G.U., San Francisco, (2009).

[2] T. Arora, N. Linde, A. Revil, J. Castermant, Non-intrusive characterization of the redox potential of landfill leachate plumes from self-potential data, J. Contam. Hydro. 92(2007) 274292. 
[3] M. Aubert, I.N. Dana, M. Livet, Vérification de limites de nappes aquifères en terrain volcanique par la méthode de polarisation spontanée, Comptes Rendus de l'Académine des Sciences de Paris 311 (1990) 999-1004.

[4] M. Aubert, I.N. Dana, J.-C. Dupuy, Application de la méthode de polarisation spontanée à la découverte des circulations d'eau souterraine en terrain volcanique, Comptes Rendus de l’Académie des Sciences de Paris 312 (1991) 325-330.

[5] M. Aubert, Q.Y. Atangana, Self-potential method in hydrogeological exploration of volcanic areas, Ground Water 34 (1996) 1010-1016.

[6] M. Béhaegel, P. Sailhac, G. Marquis, On the use of SP and ERT data to build a simple model

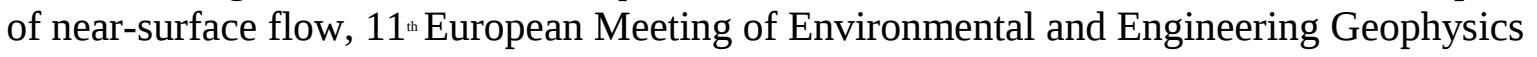
(EAGE), Palermo (2005), 4 p.

[7] F.S. Birch, Testing Fournier's method for finding water table from self-potential, Ground Water 31 (1993) 50-56.

[8] F.S. Birch, Imaging the water table by filtering self-potential profiles, Ground Water 36 (1998 ) 779-781.

[9] C. Bordes, L. Jouniaux, M. Dietrich, J.-P. Pozzi, S. Garambois, First Laboratory

measurements of seismo-magnetic conversions in fluid-filled Fontainebleau sand,

Geophys. Res. Lett. 33 (2006) L01302.

[10] C. Bordes, L. Jouniaux, S. Garambois, M. Dietrich, J.-P. Pozzi, S. Gaffet, Evidence of the theoretically predicted seismo-magnetic conversion, Geophys. J. Int., 174 (2008), 489-504.

[11]M. Darnet, G. Marquis, Modelling streaming potential (SP) signals induced by water movement in the vadose zone, J. Hydrol. 285 (2004) 114-124.

[12]M. Darnet, G. Marquis, P. Sailhac, Estimating aquifer hydraulic properties from the inversion of surface Streaming Potential (SP) anomalies, Geophys. Res. Lett. 30 (2003) 12-21.

[13] S.R. De Groot, P. Mazur, Non-Equilibrium thermodynamics. Corrected republication edition by Dover Publication, New-York, 1984; originally published in North-Holland Pub. Co., Dover, Amsterdam, 1962, 510 p.

[14] B. Diu, C. Guthmann, D. Lederer, B. Roulet, Thermodynamique, , Hermann - éditeurs des Sciences et des Arts, Paris, 2007, 730 p.

[15] C. Doussan, L. Jouniaux, J.-L. Thony, Temporal variations of SP and unsaturated water flow in loam and clay soils : a seasonal field study, J. Hydrol. 267 (2002) 173-185.

[16] J.C. Dupuis, K.E. Butler, A.W. Kepic, D.B. Harris, Anatomy of a seismoelectric conversion: measurements and conceptual modeling in boreholes penetrating a sandy aquifer, J. Geophys. Res. 114 (2009) B10306. 
[17] C.W. Fetter, Applied Hydrogeology (4 ${ }^{\text {th }}$ edition). Macmillan, New York, 2001, 298 p.

[18] D.V. Fitterman, Electrokinetic and magnetic anomalies associated with dilatant regions in a layered Earth, J. Geophys. Res. 83 (1978) 5923-5928.

[19] J.L. Fernández-Martínez, E. García-Gonzalo, V. Naudet, Particle Swarm Optimization applied to the solving and appraisal of the Streaming Potential inverse problem, Geophysics (2010), in press.

[20] S. Garambois, M. Dietrich, Seismoelectric wave conversions in porous media : Field measurements and transfer function analysis, Geophysics 66 (2001) 1417-1430.

[21] D. Gibert, P. Sailhac, Comment on the paper by Jardani, A., J.P. Dupont, and A. Revil (2006 ), Self-potential signals associated with preferential flow pathways in sinkholes, J. Geophys. Res. 111 (2008) B09204.

[22] P.W.J. Glover, I.I. Zadjali, K.A. Frew, Permeability prediction from MICP and NMR data using an electrokinetic approach, Geophysics 71 (2006) F49-F60.

[23] P.W.J. Glover, E. Walker, Grain-size to effective pore-size transformation derived from electrokinetic theory, Geophysics 74 (2009) E17-E29.

[24] X. Guichet, L. Jouniaux, N. Catel, Modification of streaming potential by precipitation of calcite in a sand-water system: laboratory measurements in the $\mathrm{pH}$ range from 4 to 12, Geophys. J. Int. 166 (2006) 445-460.

[25] P. Henry, L. Jouniaux, E.J. Screaton, S. Hunze, D. M. Saffer, Anisotropy of electrical conductivity record of initial strain at the toe of the Nankai accretionary wedge, J. Geophys. Res.108 (2003), ETG 2-1 2-12.

[26] T. Ishido, H. Mizutani, Experimental and theoretical basis of electrokinetic phenomena in rock-water systems and its applications to geophysics, J. Geophys. Res. 86 (1981) 1763-1775.

[27]M.Z. Jaafar, J. Vinogradov, M.D. Jackson, Measurement of streaming potential coupling coefficient in sandstones saturated with high salinity NaCl brine, Geophys. Res. Lett. 36 (2009) L21306.

[28]M.D. Jackson, Characterization of multiphase electrokinetic coupling using a bundle of capillary tubes model, J. Geophys. Res. 113 (2008) B04201.

[29] L. Jouniaux, Lallemant S., Pozzi J.-P., Changes in the permeability, streaming potential and resistivity of a claystone from the Nankai prism under stress, Geophys. Res. Lett. 21 (1994), 149152.

[30] L. Jouniaux, J.-P. Pozzi, J. Berthier, P. Massé, Detection of fluid flow variations at the Nankai Trough by electric and magnetic measurements in boreholes or at the seafloor, J. Geophys. Res. 104 (1999) 29,293-29,309.

[31] O. Kuwano, M. Nakatani, S. Yoshida, Effect of the flow state on streaming current, Geophys. Res. Lett. 33 (2006) L21309.

[32] A. Maineult, Y. Bernabé, P. Ackerer, Detection of advected concentration and pH fronts from self-potential measurements, J. Geophys. Res. 110 (2005) B11205. 
[33] A. Maineult, Y. Bernabé, P. Ackerer, Detection of advected, reacting redox fronts from selfpotential measurements, J. Contam. Hydro. 86 (2006) 32-52.

[34] A. Maineult, L. Jouniaux, Y. Bernabé, Influence of the mineralogical composition on the self-potential response to advection of Kcl concentration fronts through sand, Geophys. Res. Lett. 33 (2006) L24311.

[35] A. Maineult, E. Strobach, J. Renner, Self-potential signals induced by periodic pumping tests, J. Geophys. Res. 113 (2008) B01203.

[36] F. Massenet, P.V. Ngoc, Experimental and theoretical basis of self-potential phenomena in volcanic areas with reference to results obtained on mount Etna, Earth Planet. Sci Lett. 73 (1985) 415-429.

[37] B.J. Minsley, Modeling and inversion of Self-Potential data, $\mathrm{PhD}$ Thesis, Massachusetts Institute of Technology, (2007) $251 \mathrm{p}$.

[38] V. Naudet, A. Revil, J-Y. Bottero, P. Bégassat, Relationship between self-potential (SP) signals and redox conditions in contaminated groundwater, Geophys. Res. Lett. 30

(2003) 2091.

[39] V. Naudet, J.L. Fernández-Martínez, E. García-Gonzalo, J.P. Fernández-Álvarez,

Estimation of water table from self-potential data using Particle Swarm Optimization

(PSO), SEG expanded abstract 27 (2008) 1203-1207.

[40] B. Nourbehecht. Irreversible thermodynamic effects in inhomogeneous media and their applications in certain geoelectric problems. Ph. D. Thesis, 2003. Massachusetts Institute of Technology, Cambridge, Ma.

[41] L. Onsager, Reciprocal relations in irreversible processes I, Phys. Rev. 37 (1931) 405-426.

[42] D.B. Pengra, S. Xi Li, P. Wong, Determination of rock properties by low frequency AC electrokinetics, J. Geophys. Res. 104 (1999) 29,485-29,508.

[43] F. Perrier, P. Morat, Characterization of electrical daily variations induced by capillary flow in the non-saturated zone, Pure Appl. Geophys. 157 (2000), 785-810.

[44] P.A. Pezard, S. Gautier, T. Le Borgne, B. Legros, J.-L. Deltombe, MuSET : A

multiparameter and high precision sensor for downhole spontaneous electrical potential measurements, C. R. Geoscience 341 (2009) 957-964.

[45] J.W. Pritchett, T. Ishido, Hydrofracture characterization using downhole electrical monitoring, Proceedings of World Geothermal Congress, Turkey (2005).

[46] P. Sailhac, G. Marquis, Forward and inverse modelling of SP anomalies caused by subsurface flow, Geophys. Res. Lett. 28 (2001) 1851-1854.

[47] P. Sailhac, M. Darnet, G. Marquis, Electrical streaming potential measured at the ground surface: forward modeling and inversion issues for monitoring infiltration and characterizing the vadose zone, Vadose Zone Journal 3 (2004) 1200-1206. 
[48] P. Sailhac, M. Bano, M. Behaegel, J.-F. Girard, E. Falgas Paras, J. Ledo, G. Marquis, P.- D. Matthey, J. Ortega-Ramirez, Characterizing the vadose zone and perched aquifer near the Vosges ridge at La Soutte experimental site, Obernai, France, C. R. Geoscience 341 (2009) 818-830.

[49] J.H. Saunders, M.D. Jackson, C.C. Pain, Fluid flow monitoring in oilfields using downhole measurements of electrokinetic potential, Geophysics 73 (2008) E165-E180.

[50]M.R. Sheffer, Forward modelling and inversion of streaming potential for the interpretation of hydraulic conditions from self-potential, PhD Thesis, University of British Columbia (2007) 209 p.

[51]W.R. Sill, Self-potential modeling from primary flows, Geophysics 48 (1983) 76-86.

[52]M. Strahser, W. Rabbel, F. Schildknecht, Polarisation and slowness of seismoelectric signals: a case study, Near Surface Geophysics 5 (2007) 97-114.

[53] C.Vidal, G. Dewel, P. Borckmans, Au-delà de l'équilibre, Collection Enseignement des Sciences n 46, Hermann - éditeurs des Sciences et des Arts, Paris, 1994, 372 p.

[54] T. Watanabe, Y. Katagishi, Deviation of linear relation between streaming potential and pore fluid pressure difference in granular material at relatively high Reynolds numbers, Earth Planets Space 58 (2006) 1045-1051.

[55] S. Yoshida, Convection current generated prior to rupture in saturated rocks, J. Geophys. Res. 106 (2001) 2103-2120. 